\title{
Traditional fishing housing of the turkic peoples of Sayano-Altai
}

\author{
DOI: 10.31551/2410-2725-2019-5-3-373-389
}

\section{Kyrzhinakov Artur Alekseevich}

candidate of Historical Sciences, Associate Professor, Department of General History, Institute of History and Law, Khakass State University named after N. F Katanov, Russia, Republic of Khakassia, Abakan. E-mail Kyrzhinakov@mail.ru.

\begin{abstract}
Article is devoted to the historical reconstruction of traditional fishing housing of the turkic peoples of Sayano-Altai. The design and dynamics at different stages of development of these residential buildings are considered and analyzed. They were used during hunting and harvesting of pine nuts. According to the design features, their types are distinguished: single-pitched; gable with an open smoke cleft; gable with a narrow smoke cleft; gable closed; frame-pillar with a truncated pyramidshaped roof. In the XVIII-XIX centuries. they had the most wide existence and use in economic activities in the twentieth century gradually undergo a transformation, changing its structure and the substitution of the frame structures on the hut carcass type, the existence of which is in the taiga of the Sayan-Altai mountains lasts until the present day. In the twenty-first century harvest of taiga gifts it is possible to observe temporary residential buildings of frame type in the field of fisheries, but in rare cases. A comparative analysis of these dwellings of the indigenous population of Sayano-Altai is carried out, as well as a comprehensive ethnographic description, including socionormative elements. Genesis of residential buildings of fishermen is connected with the earliest stage of development of cultures of turks peoples of Sayano-Altai. Chronologically, it is not possible to establish the exact time of their appearance, but on the basis of the available historical and ethnographic material, their modification is traced. As a result, new archival, field ethnographic materials of the author and folklore texts were introduced into scientific circulation.
\end{abstract}

Keywords: Sayano-Altai; fishing housing; khakas peoples; altai peoples; tuvin peoples; shor peoples; kumandy peoples; tubular peoples; hunting; gathering pine nuts.

\section{Саян-Алтайдың түркі халықтарының дәстүрлі кәсіптік тұрғын үйлері}

\section{Кыржинаков Артур Алексеевич}

тарих ғылымдарының кандидаты, Н.Ф. Катанов атындағы Хакас мемлекеттік университетінің Тарих және құқық институтының Жалпы тарих кафедрасының доценті, Ресей Федерациясы, Хакасия Республикасы, Абакан қ., E-mail Kyrzhinakov@mail.ru.

Аңдатпа. Мақала Саян-Алтайдың түркі халықтарының шаруашылық-кәсіптік тұрғын үйлерін тарихи құрылымын анықтауға арналған. Бұл тұрғын үй құрылыстарының әртүрлі кезеңдегі өзгерістері, динамикасы және трансформациялануын зерттеуге, талдауға арналған. Олар аңшылық кәсіп пен қарағай жаңғақтарын жинау жұмыстарына арналған. Құрылымдық ерекшелігіне байланысты мынадай түрлері анықталған: бір қырлы, екі қырлы және конус түрлі. Екі қырлы үйлердің бірнеше түрі бар: екі қырлы ашық түтіндік саңылауы бар, екі қырлы тар түтіндік саңылауы бар, екі қырлы жабық, шатырдың пирамида тәріздес фрормасы бар қаңқалыбағаналы. XVIII-XIX ғасырларда олар шаруашылықта кеңінен қолданылса, XX ғасырда біртіндеп олардың трансформациялануы жүріп, құрылымы өзгереді және қаңқалы құрылымдар бөренеден жасалған үйлерге алмасады. Олар Саяно-Алтайдың тайгалық бөлігінде бүгінгі күнге дейін сақталған. XXI ғасырда тайга өсімдіктері өнімді болған жылдары кәсіптік аумақтарда уақытша каркастық тұрғын үй құрылыстары бар, бірақ олар өте сирек кездеседі. Алтайлықтар, кумандықтар, тубалар, тувалықтар, хакастар және шорцылардың кәсіптік тұрғын үйлеріне салыстырмалы-тарихи талдау жасалып, соционормативті элементтерді ескере отырып, кешенді этнографиялық сипаттама жасалған. Ортақ құрылыстық элементтер анықталып, сонымен қатар, Саян-Алтай жоталарының жергілікті тұрғындарының тайгалық құрылыстарының атауларларындағы ұқсастық анықталған. Тайгалық түркі халықтарының әдет-ғұрыптары мен дәстүрлері осы уақытша тұрғын үйлердің құрылысы мен онда өмір сүру жағдайларымен тығыз байланысты болды. Кәсіппен айналысатындардың тұрғын үйлерінің шығу тегі Саян-Алтай түркілерінің мәдениетінің ең ежелгі кезеңімен байланысты. Олардың пайда болу мерзімін анықтау мүмкін емес, бірақ қолда бар тарихи-этнографиялық материалдың негізінде олардың өзгерістерін анықтауға болады. Нәтижесінде автордың бұрын қолданылмаған мұрағат, далалық этнографиялық материалдары мен фольклорлық мәтіндері ғылыми айналымға енгізілген. 
Түйін сөздер: Саян-Алтай; кәсіптік үйлер; хакастар; алтайлықтар; тувалықтар; шорцылар; кумандықтар; тубалар; аңшылық; қарағай жаңғақтарын жинау.

\title{
Традиционные промысловые жилища у тюркских народов Саяно-Алтая
}

\section{Кыржинаков Артур Алексеевич}

кандидат исторических наук, доцент кафедры всеобщей истории Института истории и права Хакасского государственного университета имени Н.Ф. Катанова, Россия, Республика Хакасия, г. Абакан, e-mail Kyrzhinakov@mail.ru.

\begin{abstract}
Аннотация: Статья посвящена исторической реконструкции хозяйственно-промысловых жилищ у тюркских народов Саяно-Алтая. Рассматриваются и анализируются конструкция, динамика и трансформация на разных этапах развития этих жилых построек. Они использовались во время охотничьего промысла и сбора кедрового ореха. По конструктивным особенностям выделяются их типы: односкатный; двускатный; конический. У двускатных типов жилищ выделяются подтипы: двускатный с открытой дымовой расщелиной; двускатный с узкой дымовой расщелиной; двускатный закрытый; каркасно-столбовой с усечено-пирамидальной формой крыши. Если в XVIII-XIX вв. они имели наиболее широкое бытование и использование во время хозяйственной деятельности, то в XX в. постепенно происходит их трансформация, меняется конструкция и происходит замещение каркасных конструкций на избушки срубного типа, бытование которых в таежной части Саяно-Алтая продолжается вплоть до наших дней. В XXI в. в урожайный сезон таежных даров можно наблюдать временные жилые постройки каркасного типа на местах промыслов, но уже в редких случаях. Проводится сравнительно-исторический анализ промысловых жилых построек алтайцев, кумандинцев, тубаларов, тувинцев, хакасов и шорцев, также их комплексное этнографическое описание, включающие соционормативные элементы. Выявляются в большей степени общие конструктивные элементы, также в номинации таежных постройках у коренного населения Саяно-Алтайского нагорья. Обычаи и обряды тюркских таежников были тесно связаны с построением и проживанием в этих временных жилищах. Генезис жилых построек промысловиков связан с наиболее ранним этапом развития культур тюрков Саяно-Алтая. Хронологически установить точное время их появления не представляется возможным, но на основе имеющегося историко-этнографического материала прослеживается их модификация. В результате введены в научный оборот ранее не использованные архивные, полевые этнографические материалы автора и фольклорные тексты.
\end{abstract}

Ключевые слова: Саяно-Алтай; промысловые жилища; хакасы; алтайцы; тувинцы; шорцы; кумандинцы; тубалары; охота; сбор кедрового ореха.

\section{УДК/UDC-39}

\section{Традиционные промысловые жилища у тюркских народов Саяно-Алтая}

\section{А.А. Кыржинаков}

Введение. Саяно-Алтайское нагорье представляет единую историкокультурную область, в которой проживают коренные тюркские этносы, со схожими культурами жизнеобеспечения. Особое внимание историков уделено основным параметрам материальной культуры тюркских народов Саяно-Алтая, сформировавшихся в глубокой древности и просуществовавших вплоть до современности. Вместе с тем, несмотря на значительное количество научной литературы, посвященной традиционной культуре алтайцев, кумандинцев, тубаларов, тувинцев, шорцев и хакасов, по сей день имеются ряд проблемных вопросов в этнографрической области. К их числу относится не маловажный аспект по реконструкции временных жилищ этих народов. В историографии темы прослеживается не однозначная оценка этим жилым постройкам, в частности у хакасов. Например, Ю.А. Шибаева рассматривая жилые постройки хакасов, приходит к выводу, что «одах» (промысловое жилище - К.А.) и «ат иб» (постоянное стационарное жилье каркасно-столбовой конструкции таежной 
группы хакасов - К.А.) являются одним типом жилья. На наш взгляд этот и другие аспекты требуют специального научного исследования. Актуальность тематики определяется тем, что также не в полной мере освящены вопросы сравнительно-исторического анализа, трансформации временных жилищ у тюрков Саяно-Алтайского нагорья, что послужит важным дополнением при исследовании горно-таежного культурного комплекса народов Сибири.

Материалы и методы. В основе источниковедческой базы лежат полевые материалы автора, архивные, лингвистические и фольклорные материалы, позволившие раскрыть избранную тему. Сбор полевого материала производился в рамках этнографических экспедиций с 2003 по 2018 гг. на территории Республики Хакасия в местах компактного проживания хакасского этноса. В качестве архивных материалов привлечены рукописи этнографов П.И. Каралькина, Ю.А. Шибаевой, посвященные жилым постройкам хакасов, из рукописного фонда Хакасского научно-исследовательского института языка, литературы и истории. Важным дополнением при написании нашей работы явились фоольклорные материалы, в которых имеются сведения о разных типах временных жилищ. В качестве источника была использована «Сравнительно-историческая грамматика тюркских языков».

В работе применен комплексный подход, позволивший использовать результаты разных направлений гуманитарных наук. В нашем исследовании были использованы традиционные этнографические и общенаучные методы. Традиционные методы: опрос, беседа, наблюдения применялись во время этнографических полевых исследований для сбора полевого материала. При описании и классификации конструктивных особенностей сезонных жилищ промысловиков Саяно-Алтайского нагорья послужили описательный и типологический методы. С целью выявления общих и локальных элементов в историческом развитии этих жилых комплексов на Юге Сибири был использован сравнительно-исторический метод. К тому же методы анализа и синтеза позволили объективно интерпретировать собранный историкоэтнографический материал по данной теме.

Обсуждение. Промысловые жилые постройки на территории СаяноАлтайского нагорья рассматривались в контексте общей тематики в работах исследователей дореволюционного периода Н.М. Ядринцева (Ядринцев, 1893); А.А. Кузнецовой (1898), Е.К. Яковлева (1900). К сожалению, в этих работах встречаются отрывочные сведения о жилых временных сооружениях и постройках тюрков Саяно-Алтая. Так, Н.М. Ядринцев отметил, что «Эти жилища состоят из шалашей, покрытых ветвями, корою, наконец, берестой (финские кота)», они еще существуют у горных и лесных жителей Алтая (аланчик, оодаг)» (Ядринцев, 1893: 115). В сочинении А.А. Кузнецовой указаны краткие сведения о жилище каркасно-столбовой конструкции: «что особенностью ат иб была его низкая стоимость (3-5 руб.), простота изготовления - можно было изготовить одним человеком за три дня и достаточно его широкое распространение в летниках, зимниках, заимках и таборах Абаканской и Аскизкой управах» (Кузнецова, 1898:112). Е.К. Яковлев, изучая традиционные типы жилищ коренного населения Хакасии, полагает, что ат иб представляет первый переход от алачыха к постоянному жилью (Яковлев, 1900: 32).

Этнографрические описания по традиционным жилищам алтайцев имеются в исследованиях В.В. Радлова (Радлов, 1989: 138-139), В.И. Вербицкого (Вербицкий, 1858:105-106). 
В XX в. традиционные временные жилые постройки Саяно-Алтаских тюрков более подробно освещены в трудах отечественных этнографов Л.П. Потапова (Потапов, 1936; 1957; 2001), Ю.А. Шибаевой (Шибаева,1954), А.А. Попова (Попов, 1961), К.М. Патачакова (Патачаков,1984), В.Я. Бутанаева (Бутанаев, 1987), С.И. Вайнштейн (Вайнштейн, 1991) и Е.П. Соколовой (Соколова, 1998).

Л.П. Потапов упоминает о бытовании у хакасов примитивного (шорского типа) шалаша, называемого ими - «одаг». Он пишет: «У хакасов имелся видоизменённый тип шорского одаг, под названием «ат-иб», покрытие которого состояло из коры лиственницы. Жилище хакасов «ат иб» имело распространение у родоплеменных групп сагайцев, койбалов и бельтыр» (Потапов, 1957: 275). Он также оставил этнографические сведения о промысловых жилищах алтайских тюрков (Потапов, 2001: 94).

Ю.А. Шибаева, описывая конструкцию жилища сагайцев ат иб, отмечает, что оно чаще имеет название одах (рис. 1): «По кругу в землю вбиты шесть столбов (трис), образуя внутри его шесть стен» (Шибаева, 1954: 42). Её описание одаг входит в известную классическую работу по жилищам коренных народов Сибири А.А. Попова (Попов, 1961: 150).

В исследовании А.А. Попова впервые дается классифрикация жилищ народов Сибири, в которой жилые постройки таежников охарактеризованы по конструктивным особенностям (Попов, 1961: 131-227).

К.М. Патачаков связывал бытование жилища одаг с таёжными промыслами и земледелием. Хакасы-земледельцы и охотники в тайге строили шалаш, который называли отах. Стены его, как у корьевой юрты, делали из круглых жердей, горбылей или широких досок. Крыша делалась из жердей решеткой в выпуклой форме. Посередине над очагом оставлялось дымовое отверстие. Отах для тепла снаружи обкладывался земляным дерном или до середины засыпался землей. Такие отах бытовали в 20-30-х гг. XX в. в Каройских степях, на пашнях и покосах тейских жителей Аскизского района. Кроме того, ат иб (второе название хахпас иб) и отах, как отмечает К.М. Патачаков, имели совершенно одинаковую конструкцию, их различие заключалось только в назначении. Отах был временным жилищем, ат иб постоянным (Патачаков, 1984: 18).

Во второй половине XX в. встречаем сведения об одаг в исследованиях В.Я. Бутанаева. Автор отметил одаг в основном в обычаях и правилах быта охотников (Бутанаев, 1987: 27).

В работе С.И. Вайнштейна раскрываются вопросы материальной и духовной культуры, проблемы генезиса жилищ у тувинского этноса. Автор в ней также рассмотрел временные жилища коренного населения Тувы (Вайнштейн, 1991:14)

В конце XX в. вышла в свет работа 3.П. Соколовой, посвященной жилищам народов Сибири. Автор провела типологию различных конструкций жилищ народов Сибири (Соколова: 1998).

B XXI в. имеются ряд работ, в которых освящены некоторые аспекты нашего исследования. Исследователи проблем развития южносибирского лесного культурного комплекса - А.Г. Селезнев, И.А. Селезнева, Е.А. Бельгибаев, приводят сведения об односкатных, двускатных типах жилищ таежников (Селезнев и др.: 95).

В этот период были опубликованы академические труды, посвященные тюркским народам Сибири. Большинство авторов рассмотрели традиционные культуры тюркских этносов Саяно-Алтая, в которых имеются описания 
временных промысловых жилых построек (Тюркские народы Сибири, 2006; Тюркские народы Восточной Сибири, 2007).

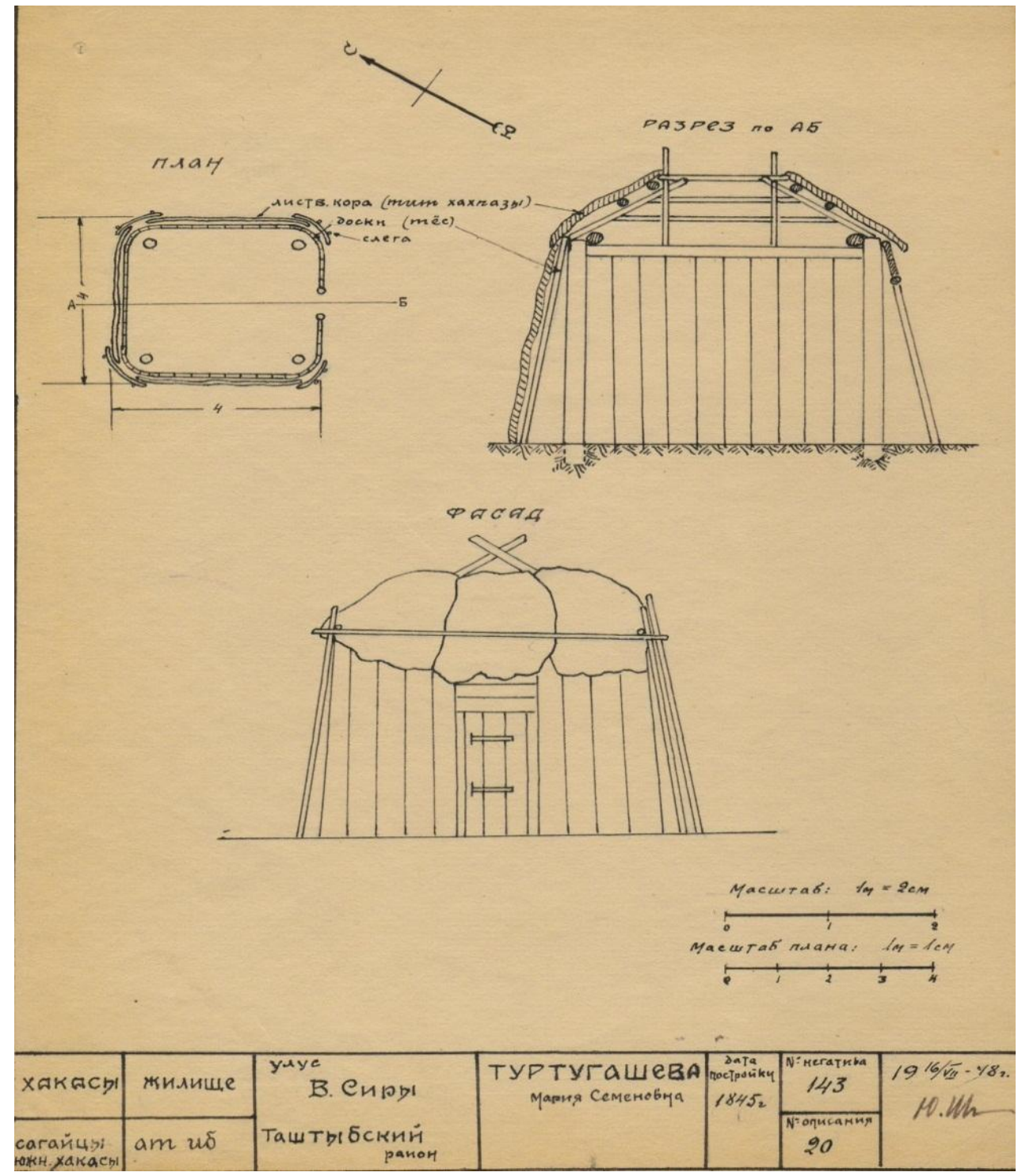

Рисунок 1. Жилище хакасов ат иб (РФ ХакНИИЯЛИ, Шибаева, Чертежи по жилищу хакасов)

В данное время была опубликована работа В.К. Даржа, раскрывающая традиционные мужские занятия тувинцев. Автор обратил внимание на охотничье жилье всех этнических групп тувинского этноса (Даржа, 2009: 114116).

В 2012 г. была издана работа О. Ильиной, посвященная народной архитектуре народов Алтая, от древности до настоящего этнографического времени. Внимание автора привлекли конструктивные особенности промысловых жилищ алтайцев (Ильина, 2012: 225-226).

В XXI в. сведения о трансформации шорского одаг имеются в работе В.М. Кимеева, отметившего, что: «Каркасный одаг являлся традиционным жилищем предков шорцев, который в конце XIX в. был заменен срубной бревенчатой прямоугольной в плане юртой» (Кимеев, 2018: 343). 
Таким образом, историографический обзор показывает, что промысловое жилище не стало предметом специального исследования, а рассматривалось учеными в контексте общей тематики, посвященной традиционной культуре коренного населения Саяно-Алтайского региона.

Результаты. В традиционной системе жизнедеятельности у тюркских народов Саяно-Алтая существовали различные типы жилищ, приспособленные к горно-таежным, горно-степным условиям региона. Среди традиционных типов жилища тюркских народов Саяно-Алтая выделяются промысловые временные, занимавшие значительное место в их хозяйственном укладе. У тувинцев временное промысловое жилье называется чавыт/чавыт чадыр, у хакасов одаг/отах, у алтайцев - јапаш/чадыр, у шорцев - одаг, у кумандинцев адаг/одаг, у тубаларов - адаг/одаг. К тому же тувинцы во время промысла для ночлега сооружали навес, называвшийся сери, а зимой алачик (Даржа, 2009: 114). Следует отметить, что термином одаг у шорцев - это жилище из бревен, жердей и веток для промысловиков-сборщиков кедрового ореха; жилище летнего типа, свадебный шалаш-одаг; зимнее жилище у бедняков; во время полевых работ навес на столбах без стен с покатой крышей из колотых бревен (Кимеев, 2018: 301, 343, 346, 348).

Номинация отах/одаг являются производными от глагола ота - зажигать огонь, костер. Первоначально слово обозначало место для костра, охотничий стан, временное жилище (Сравнительно-историческая..., 2001: 496). В этом значении термин одаг, например, сохранился в современном тувинском языке. «Охотничью стоянку называют одаг - букв. костер, «место остановки на одну ночь». Основой охотничьей стоянки является костер - одаг. Поэтому и название охотничьей стоянки на тувинском языке - одаг связано с наименованием огня» (Даржа, 2009: 114-116). По совокупности сведений информантов представляется возможным выделить несколько типов одаг у хакасов: чамдых отах - односкатный шалаш, от отах - шалаш крытый сеном, чарты одаг - дощатый одаг, туюх одаг - закрытый тип шалаша/двускатный тип (ПМА-1). Все эти временные жилище сходные по конструкции бытовали у всех тюркских народов Саяно-Алтая. О бытовании разного типов временных жилищ у тюркского населения рассматриваемого региона свидетельствует также фольклорный материал. Например, в хакасском фрольклорном наследии встречаются сюжеты о жилище одаг и связанные с ним обычаи и обряды. Например: «От отахта чадып халган паланы, Алып кізілер пілбин халган поладыр, от отахтын тубіне кіріп чадып чададыр хыс пала» (Антология..., 19: 11) - Внутри шалаша, крытым сеном, укрылась девочка, ее не заметили богатыри (текст переведен - А.К.). Упоминание о дощатом типе одаг встречаем в сказке о Стрелке Хыйар: «Когда-то в долине Абакана жили три охотника. Однажды они ушли охотиться за Енисей, в тайгу, по рекам Кизир и Казыр. Из разрубленных бревен смастерили охотничий балаган, отметили его постройку праздником отах тойы, как положено по законам тайги (Бутанаев, Бутанаева, 2015: 120).

На основе имеющегося историко-этнографического материла по конструктивным особенностям можно выделить несколько типов временных жилищ: односкатные, двускатные, конические. Односкатный тип представлял собой временное жилище на ночлег. У хакасов его основу составляли четыре жерди или две вильчатые на конце обрубка дерева, высотой около 1,5 м. Каждые по две жерди соединялись (привязывались), образуя рогатину, на которую по бокам пропускали две тонкие жерди, толстые их концы упирались на землю. Соединялась конструкция верхней части продольной жердью, на 
которую клали ветки, лапник, тонкие жердочки хвойного дерева. На открытой стороне разжигали огонь так, чтобы тепло исходило вглубь временного жилища. Спали ногами к костру. Этот тип в основном служил для переночевки (ПМА-3). У тувинцев сооружение подобной конструкции называется сери. Так, В.Я. Даржа пишет: «Сери - это открытый с одной стороны скат крыши, прикрывающий костер и место ночлега с северной стороны. Для одного человека навес возводился стороной, обращенной к костру, длиной 2 метра и высотой не более 1,5 метра. В зависимости от количества увеличивалась до 2х метров только глубина навеса, при этом охотники ложились ногами к костру (Даржа, 2009: 114).

Второй тип - двускатный. У этого типа можно выделить два подтипа: каркасно-столбовой конструкции с усечено-пирамидальной крышей: каркасностолбовой конструкции с открытой и закрытой дымовой расщелиной. Первый подтип предназначался для более длительного пребывания во время промысла. По конструктивным особенностям этот тип соотноситься с постоянным жилищем ат иб у хакасов. Каркас его крыши сооружали также в виде решетки из тонких жердей, которую покрывали корой лиственницы. Ее сверху придавливали расколотыми тонкими досками, жердями, как и у жилища ат иб. В центре крыши оставляли отверстие, служившее дымоходом. Стены сооружали из колотых досок, слегка с уклоном. Вход ориентировался на восток. Дверь была из колотых досок. Очаг располагался в центре. Промысловики в одаг размещались вокруг огня (ПМА-3). Например, хакасский одаг каркасного типа с усечено-пирамидальной крышей существовал в середине XX в. в таежных местностях Нымыртах, Хузухтыг (ПМА-3). По сведениям информантов ат иб являлся постоянным жилищем у бедного населения, бытовавшим еще в середине XX в. Например, в ат иб жил Пизен Кайлачаков в аале Картоев Аскизского района (ПМА-2). Его конструкция имела общие черты с постоянным жилищем ат иб - состояла из четырех опорных столбов, в верхней части соединенных деревянной рамой. Аналогичной конструкции промысловое жилье бытовало у шорцев, которое также называлось одаг (Потапов, 2001: 94). У алтайцев также строили двускатные шалаши с продольной балкой, к которой прислоняли небольшие жерди, ветки каркас закрывали корой, дополнительным утеплителем служили трава, земля, снег (Ильина, 2012: 226). Второй подтип представлял собой двускатный каркасный шалаш, в основании которого находились четыре вильчатых столба установленных вертикально. Вверху они были соединены деревянной рамой. В качестве рам служили обтесанные жерди. Столбы были диаметром около 15 см., а высотой около двух метров. Стены строили из тонких жердей и веток хвойных деревьев: пихты и ели. Тонкие жерди наклонно приставлялись к каркасу шалаша так, чтобы верхние концы не сходились. Так образовывалась открытая дымовая расщелина около 80 см. В качестве крыши служили естественные ветки хвойных деревьев, так как промысловое жилище строили под ними. Вход был открытым и ориентировался на восток (ПМА-1). Вариант изготовления третьего типа у хакасов, когда его стены строили из колотых досок, получил номинацию - чарты одаг - букв. в переводе «дощатый одаг». В его конструкцию были внесены незначительные изменения - опорные столбики каркаса водружали на расстоянии более близком друг к другу и соединяли их коньковой жердью. Дымовая расщелина соответственно была уже и составляла около 20-30 см. (рис. 3). Этот подтип жилища известен был и у алтайцев. По материалам О.П. Ильиной: «Каркас таких жилищ был из четырех стоек, к которым приставлялись жерди, доски и плахи. После ночевки 
временные жилища оставляли, особенно если они были сооружены на путях, для других путников оставляли каркас, от охотничьих жилищ оставляли каркас, который использовался в следующем году (Ильина, 2012: 226).

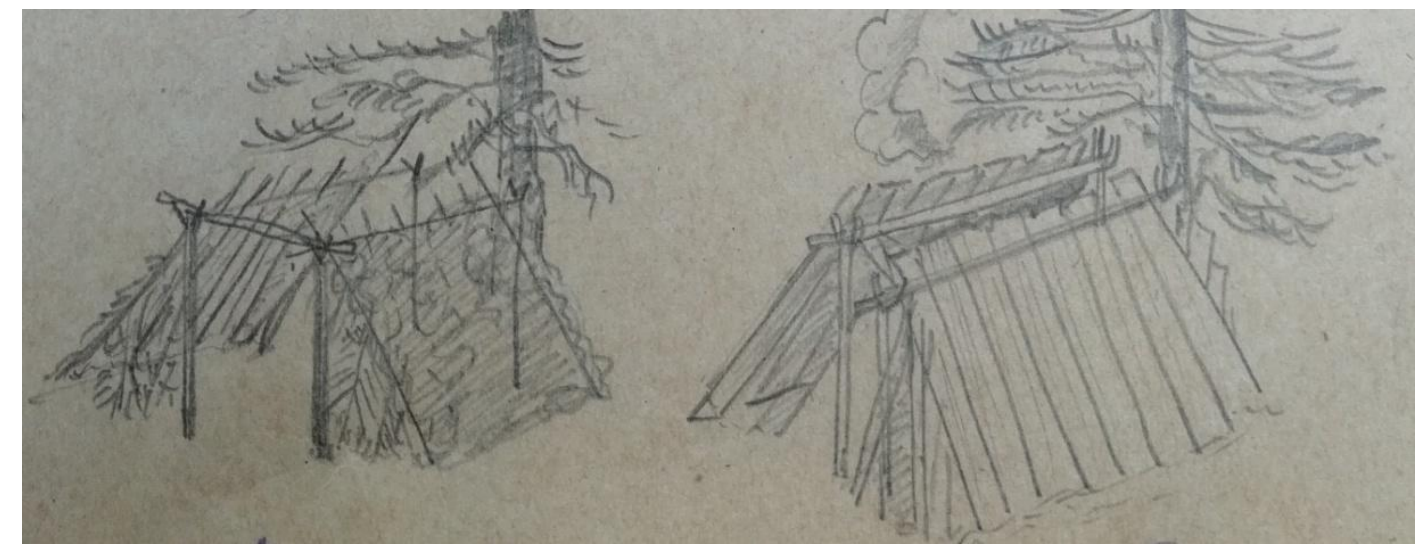

Рисунок 2. Промысловое жилье из тонких жердей, сучьев и колотых досок (РФ ХакНИИЯЛИ. № 341. Каралькин П.И. Земледелие и охота у бельтыров.

(по материалам экспедиции в Аскизский и Таштыпский районы в 1947 г.) - 40 с.)

К тому же схожей по конструкции жилище представляло собой двускатный также прямоугольной фоормы каркасно-столбовой конструкции закрытого типа. Его каркас состоял из двух опорных столбов, высотой около двух метров, соединенных в верхней части продольной балкой. К ним в передней и задней частях устанавливали наклонно на каждой стороне обтесанные жерди или колотые доски, что являлось частью основы шалаша. В некоторых случаях вместо столбов использовали рядом растущие два дерева, т. е. сооружали одаг под ними (ПМА-1, 2). Другая вариация конструкции этого подтипа одаг предполагала использование вместо одного из опорных столбов только одного дерева. Затем строили стены из колотых досок, также из пихты, ели. Сначала перекрывали переднюю и заднюю часть одаг, а затем боковые стены. Щели между досками конопатили мхом. Нижнюю часть вокруг обкладывали дерном. В передней части находился вход в одаг, ориентированный на восток с дощатой дверью. Дверь крепили петельным способом. Одаг имел закрытый тип крыши. Внутри в правой части от входа устанавливали железную печь (буржуйку) с трубой. Место для печи укладывали камнями. В жилище сооружали деревянные нары из колотых досок или жердей, высотой около 4050 см. от земли (ПМА-1, 2). Данный тип одаг - туюх одаг имел трансформированную конструкцию и практиковался еще во второй половине XX в. Например, подобные одаг были в долине р. Теи Аскизского района в таежной местности «хузуг итчен холл» - букв. переводе «лог, где орешничают» (ПМА-1).

О промысловых шалашах алтайцев говорилось: «В черневой тайге во время орехового промысла возводили шалаши из пихтовых жердей, накрытых пихтовыми ветками. Здесь также сооружали и долговременное охотничье жилье на несколько лет. Оно примерно имело размеры:3,5×3,5×2,5 и было ориентировано по сторонам света. Каркас его возводили над небольшим углублением в земле. Опорные столбы соединялись продольной балкой. В стропила в столб врубали поперечину, служившую верхним косяком двери. Двускатную крышу и фрронтоны закрывали полубревнами, поверх которых 
настилали бересту, а затем укладывали пласты земли. Самое несложное жилье охотники устраивали на одну ночь под ветками пихты и кедра. Охотник находил подходящее дерево, от его ствола отгребал снег, пригибал ветки к земле. Затем стены такого импровизированного жилища дополнительно укладывались срубленными ветками и присыпались снегом» (Ильина, 2012: 224-225).

Конической формы жилище было распространено по всей территории Саяно-Алтайского нагорья. Однако использовался в качестве промыслового жилья у тувинцев (Даржа, 2009: 114). Так, о тувинском коническом жилье указано: «В местах проведения больших осенних и зимних охот тувинские охотники традиционно возводили чумы относительно большого размера чадыр, которыми пользовались в течение нескольких лет». Он представлял собой конус диаметром в основании 4-8 метров, стены состоят из каркаса, собранного из жердей и покрышки (Даржа, 2009: 113-114). У хакасов он именовался алачых, но являлся уже обрядовым жильем во время свадьбы. У шорцев этот тип жилья назывался одаг, который как у хакасов использовался во время свадьбы для молодожен (Кимеев, 2018: 343). У алтайцев конической формы жилище являлось постоянным. Он назывался аланчик, содон аил, чаадыр и солтон (Ильина, 2012: 214). К тому же у таежных алтайцев он использовался также во время свадьбы. Об этом отметил В.И. Вербицкий «... но утру приготавливают супружеский одах, состоящий из 9-ти длинных, тонкоствольных березок, примерно арш. вышины, с очищенными от комля сучьями, а наверху оставленными в виде метелки. Вершины всех березок связывают верёвкой. Разводят комли в разные стороны, отчего и делается остов юрты или шалаша под венком березовых листьев. Остов этот покрывают берестой с помощью веревок, оставляют в них вход» (Вербицкий, 1858: 105-106).

Генезис временных жилых построек связан с наиболее ранним этапом развития культур южносибирских тюрков. Как уже отмечено, однотипные временные укрытия и жилые постройки бытовали у таежных хакасов, челканцев, кумандинцев, шорцев, алтайцев и тувинцев. Хронологически установить точное время их появления не представляется возможным, но на основе имеющегося историко-этнографического материала прослеживается их модифрикация. В процессе исторического развития хакасский одаг прошел ряд конструктивных изменений, от односкатного до двускатного с несколькими вариантами кровли верхней части и боковых стен. К наиболее первому типу временного жилья следует отнести односкатный тип, сооруженный из тонких жердей и веток. Это прослеживается также в номинации как чамдых одаг - т. е. половина одаг. У тувинцев имел название - сери. В основном он предназначался для укрытия во время ночлега. Впоследствии два соединенных односкатных укрытия стали одаг с широкой дымовой расщелиной выполнявшие функции уже как временного жилья. К последним усовершенствованиям в домостроении таежников Саяно-Алтая следует отнести одаг из колотых досок, жилье с узкой и закрытой дымовой расщелиной, служившее наиболее длительный период времени в отличие от выше отмеченных. Следует остановиться на трансформации их как временного жилья таежников. C 80-х гг. XX в. для более комфрортного пребывания в суровых таежных условиях, они стали ставить железные печи и сооружать нары. В XIX в. постепенно в промысловых местах у шорцев, а в XX в. у хакасов, алтайцев, тувинцев наряду с ними стали появляться срубные конструкции избушек, что послужило одним из фракторов постепенного исчезновения традиционного 
временного жилья. Однако по полевым материалам промысловые жилища из веток и жердей у хакасов приходилось наблюдать в начале 2000-х гг. когда был урожайный период кедрового ореха в Хакасии. В местности Хузух итчен хол лог кедрового промысла, помимо турачах, промысловики построили два одаг из жердей и веток. По исследованиям К. М. Патачкова и полевым материалам один из типов - одаг/туюх одаг с усеченно-пирамидальной крышей соотносится со стационарным типом жилья ат иб таежных хакасов. Исследователь жилищ якутов Ф.М. Зыков проводит генетическую параллель между балаганом и хакасским жилищем «ат иб», предполагая южные истоки его конструкции (Зыков, 1986: 3). Это предположение подтвердилось данными археологии карасукского времени X-IX вв. до н. э., с открытием Д.Г. Савиновым жилища Торгажака в Хакасии с конструкцией как у якутского балагана (Савинов, 1996). Древность жилища ат иб у таежных хакасов не вызывает сомнения, его прошлое уходит ещё в дотюркское время.

B XIX в. по Своду степных законов хакасов все промысловые угодья стали общими и юридически закреплялись по праву первозахватного владения. Основанием для закрепления таежного участка являлся установленный на нем одаг. Нам известно, что на местах промысла для закрепления территории ставили одаг. Например, в долине по р. Джебашу находились участки Онас одаг, Плат одаг и т. д.; по р. Б. Июс - Прок одаг, Ториче одаг и др. За разрешение охотиться на закрепленном участке чужие охотники платили 5 руб. (царских монет) и ставили угощение главе охотничьего угодья. В некоторых случаях они выплачивали стоимость шкурками пушных зверей - от 30 до 50 белок (Бутанаев, 2004: 95). По охотничьим законам, промысловые угодья были разделены между родами и не являлись предметом споров. У всех хакасских родов существовали свои территории промысла. В редких случаях если кто-то без разрешения промышлял на чужой территории, то у него отбирали всю добычу и даже телесно наказывали 25 ударами розг (ПМА-1).

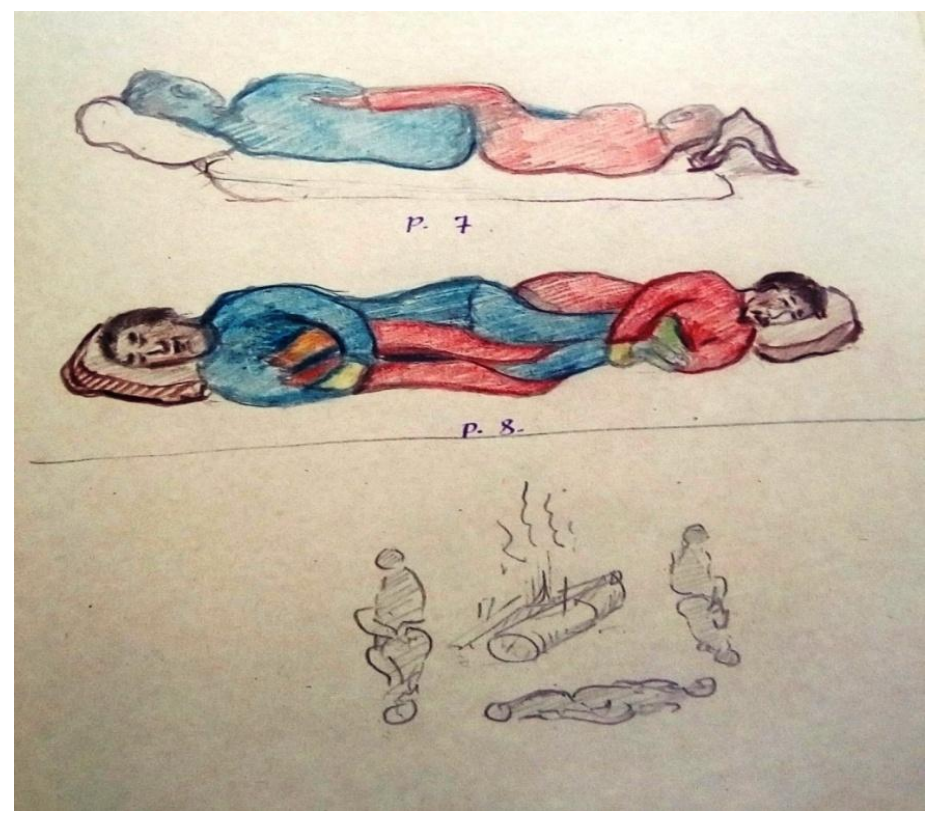

Рисунок 3. Ночной отдых промысловиков (РФ ХакНИИЯЛИ. № 341. Каралькин П. И. Земледелие и охота у бельтыров. (по материалам экспедиции в Аскизский и Таштыпский районы в 1947 г.) - 40 с.) 
У всех отмеченных типов одаг площадь варьировалась от 4,5 до 8 кв. м. и редко была большей. Внутреннее пространство одаг так же, как в других видах жилищ, делилось в социальном отношении, что, на наш взгляд, свидетельствует об его некогда постоянном характере. Место за очагом - тор считалось почетным. На нем располагался глава артели - одаг пазы, в левом углу ближе к берестяному туесу с хакасским квасом - абыртха. Остальные члены артели, как правило, были разных возрастов. Молодые охотники, выполняли второстепенные работы - приносили воду и дрова, они же занимали места в одаг перед очагом, возле входа. Другие охотники занимали места вдоль стен. Огонь звероловы поддерживали всю ночь. Для длительного горения костра огонь разжигали особым способом - «от нарыиы»: два бревна клали друг на друга горизонтально и в таком положении они могли гореть всю ночь. Этот способ обогрева был заимствован тувинцами, которые называли его «саиай оды» - «сагайский огонь». Спали охотники вокруг огня, настелив пихтовые ветки и свою одежду, укрывались также одеждой. Во время сна каждый промышленник ложился на свое место, повернувшись спиной к костру. Спали также парами валетом - «азагызап» (рис. 4). В этом случае ноги клали так, чтобы они упирались в грудь другого напарника. Если один из спящих в такой позе хотел повернуться на другой бок, он будил второго, предлагая ему сделать это.

Промысловый стан имел свои дополнительные подсобные сооружения для хранения провизии. Как правило, боеприпасы и ружья хранили вне одаг с целью обезопасить их от огня. Огнестрельное оружие вешали на шест сарчын (столбик или дерево). Существовал лабаз для продуктов высотой около двух метров (рис. 5). Его обычно сооружали из жердей (ПМА-1). Аналогичное по конструкции лабаз для продуктов существовали у шорцев, называемый по-шорски тастак (Потапов, 2001: 95).

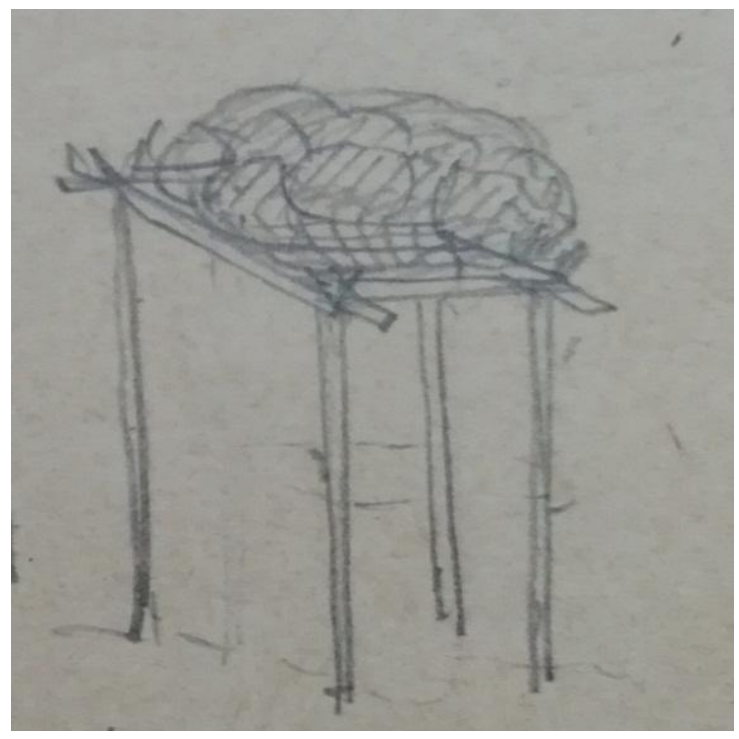

Рисунок 4. Лабаз для продуктов (РФ ХакНИИЯЛИ. № 341. Каралькин П. И.Земледелие и охота у бельтыров. (по материалам экспедиции в Аскизский и Таштыпский районы в 1947 г.) - 40 с.)

Во время промысла охотники придерживались таёжных обычаев и обрядов. Прибыв на место промысла, первым делом выбирали место для одаг. Как правило, звероловы строили жилище, как мы отмечали выше, под хвойным 
деревом. По охотничьим поверьям, такое дерево должно быть с удачей (таланныг агас) (рис. 6). Выбирали его по следующим приметам: теплое дерево имеет иней, а холодное не имеет, дерево с удачей имеет пологие сучья (РФ ХакНИИЯЛИ. № 341. Каралькин, 1947: 23). У алтайских тюрков также было развито представление о месте выбора для жилья по дереву (Потапов, 2001: 95).

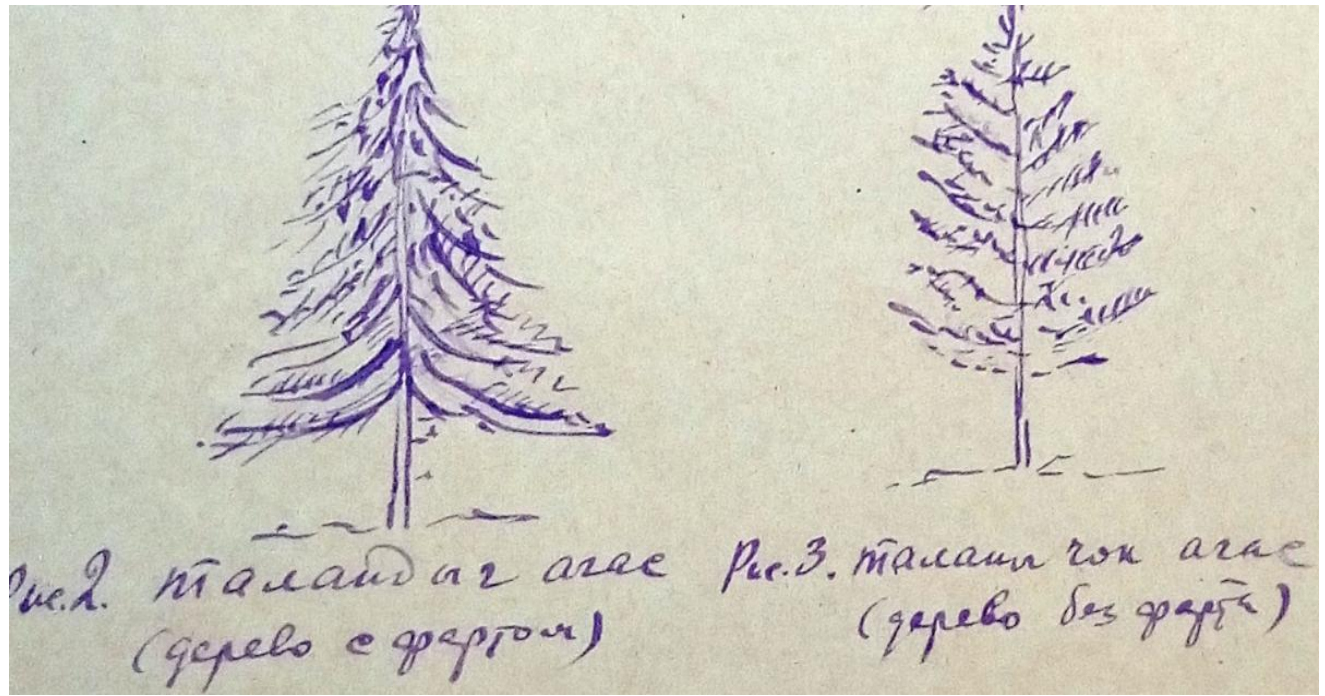

Рисунок 5. Деревья с «фрартом» и «без фрарта»

(РФ ХакНИИЯЛИ. № 341. Каралькин П.И. Земледелие и охота у бельтыров. (по материалам экспедиции в Аскизский и Таштыпский районы в 1947 г.) - 40 с.)

Перед постройкой на месте одаг расчищали снег с помощью лыжной палки - курчек, являвшейся универсальным орудием охотника. На сооружение одаг из жердей, веток пихты, ели, кедра требовалось меньше времени и затрат, чем из колотых досок. Инструментами для постройки служили топор палты/малты, пила - кірее, нож - пычах и деревянные клинья - сыынчах. Для постройки использовали доски, которые кололи с помощью топора и деревянных клиньев. Одаг строили в течение светового дня. Если промысловиков было более шести, то строили два шалаша. Один из них являлся базовым, называемый по-хакасски - тим одаг. В этом одаг располагался глава артели, который получал ежедневную добычу у других членов артели, при этом следил за сохранностью пушнины, например, в случае необходимости мог ее сушить. При добыче особо ценных зверей он устраивал по обычаям предков пиршество - «той». К тому же он следил за разжиганием огня (при разжигании очага дрова клали вершиной в огонь, а комлем наружу) и питанием охотников (Бутанаев, 1996: 146).

Выбрав место, глава артели обращался к горным духам, хозяевам этих мест (ээлерге) со словами: «Мы здесь выбрали место, разрешите нам устроиться». Затем один из охотников варил мясной суп, остальные сооружали одаг. После установки совершали обряд «пус тутча», т.е. кормление священным паром горных духов «Таг ээзи» и верховного божества. Для этого сваренное мясо вытаскивали и клали в берестяное или деревянное корытце и поднимали вверх. По верованиям хакасов, этот священный пар (оор-пус) доходил до хозяев гор и верховного божества. Затем совершали обряд кормления богини огня «от ине». Этот обряд совершали следующим образом. 
В горящий костер бросали кусочки мяса и сала, брызгали абырткой (квасом) или молочным вином (айран арагызы) при этом приговаривали: «Тридцатизубая моя Богиня огня, сороказубая моя Дева мать, божественнее Вас никого нет. От Ульгена ты частью, светом светящая. Мы сами не ели, мы не пили, Вам преподносим наш дар. Мерзлое оттаиваешь, растаявшее варишь, Богиня огня, не серчая, отведай наш дар. Вечером ты в шелке, в золотой шубе. С луком с золотой тетивой, если нечистая сила придет, оберегай нас. Перегораживай путь сатане золотой тетивой. Ставь впереди нас, далекого не отправляй, ближнего не прячь» (РФ ХакНИИЯЛИ. № 925. Патачаков К.М. Религиозно-бытовые пережитки у хакасов и пути их преодоления. Л-9). Из заклинания можно узнать, что охотники просили у богини огня «От-Ине» покровительства и защиту от злых духов. В настоящее время этот обряд также совершается таежниками, но заклинание претерпело изменения - стало коротким. Так, по сведениям информантов, в горящий огонь также бросают кусочки мяса и сала и кропят разными напитками. Они при кормлении «ОтИне» говорят: «Талан ползын, алнындагы чолыбыс азых ползын, кистіндегізі туюх» - «Пусть будет удача, чтобы дорога была без преград» (ПМА-1). В первый день, после установки одаг совершали «одаг тойы» - пиршество в честь его установки. Для этого варили мясной суп, разводили хакасский квас «абыртхы» и совершали им кропление духам окружающих гор с просьбой: «Поставьте перед нами зверей с раздвоенным копытом, посадите на сучья птиц с каурыми крыльями!». Мясо добытых зверей употребляли только в вареном виде. Запрещалось жарить пищу, так как жареное мясо дает гарь «хуюх», которой питаются души умерших людей. Перед возвращением из тайги охотники разбирали свое ложе в одаг и звали домой жизненную силу «хут» (Бутанаев, 2003: 36). Все вышеперечисленные обряды всегда выполнял самый старейший и опытный охотник. Аналогичные обычаи и обряды были у алтайцев, шорцев, кумандинцев, тубаларов (Потапов, 2001:87-104), тувинцев (Вайнштейн, 1991: 234-239). Алтайцы, также прибыв на место охоты или сбора ореха, построив шалаш, совершали обряд. «...После этого начинали обряд жертвоприношения: завязывали ленточку материи (кыйра), затем молоком, самогоном или ячменной кашицей (шилиг) совершали кропление духам, исполнения благопожелания (алкыш). Жертву посвящали хозяину тайги, кедру под которым выстроен шалаш» (Ильина, 2012: 225).

Со второй половины XX в. в связи с развитием и распространением повсеместно срубной техники изготовления жилищ и построек всё чаще появляются более надежные сезонные жилища - турачах (рис. 6) на местах промысла хакасов.

Так, жилище - одаг постепенно к концу XX в. в таёжной части Хакасии полностью выходит из применения. Вместе с тем территории, где ранее находились одаг, сохранили свои прежние наименования, например - черкас одаа (ПМА-3).

Заключение. В XIX - начале XXI вв. отмечается бытование и использование сезонных жилищ в материальной культуре тюркских народов Саяно-Алтая. Исследователи выделяют четыре основные исторические конструктивно близкие формы жилища, односкатный, двускатный, конический. Двускатный с подтипами: открытый с широкой дымовой расщелиной, с усечено-пирамидальной кровлей. Последний соотносится со стационарным жилищем ат иб, который по конструкции имеет конвергенцию с жилищем древнего населения карасукской археологической культурой X - IX вB. до н. э. Хакасии. Ат иб как один из типов жилья у таежных хакасов перестал бытовать 
во второй половине XX в. Конические временные жилища бытовали у тувинцев и алтайцев.

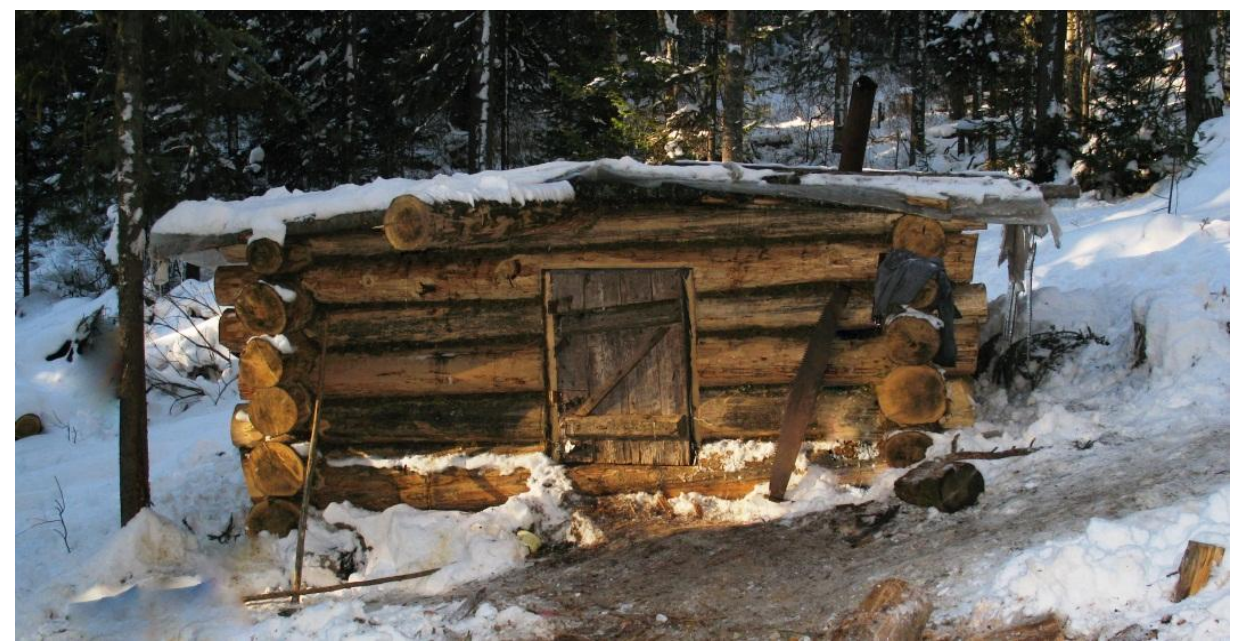

Рисунок 6. Турачах (промысловое жилище) в таежной местности Аскизского района Республики Хакасия, 2005 г. (Фото из личного архива автора)

В процессе своего исторического развития на протяжении XX в. промысловое жилье тюркских народов Саяно-Алтая проходит ряд изменений. Наиболее ранним был односкатный, его постройка требовала минимума трудовых усилий, а обогрев осуществлялся от костра, находившегося рядом. Далее развитие одаг шло по пути его усовершенствования, шалаш стал двускатным с широкой дымовой расщелиной, а очаг располагался уже внутри. Позднее стали появляться жилища из колотых досок с менее узкой дымовой расщелиной. В XX в. стали сооружать их с закрытой крышей с дымовым отверстием. Он преобразился - внутри появились нары и железная печь, но наряду с ними бытовали и простые конструкции жилища из тонких жердей и лапника хвойных деревьев.

В XX В. происходят постепенные его конструктивные изменения и трансформация, в результате чего в промысловых жилищах появляются железные печи и нары, также происходит его замещение на небольшие сезонные избушки срубного типа, бытование которых в таежной части СаяноАлтая продолжается вплоть до наших дней.

\section{Әдебиеттер тізімі / Список литературы}

1. Антология хакасской поэзии, 1960. - Антология хакасской поэзии /сост. У.Н. Кирбижекова, Т.Г. Тачеева, П.А. Трояков. Абакан: Хакасская областная типография, 1960. - 164 с.

2. Бутанаев, 1987. - Бутанаев В.Я. Социально-экономическая история хакасского аала (конец XIX - начало XX в.). - Абакан: Краснояр. кн. изд-во, Хакас. отд-ние, 1987. - 175 с.

3. Бутанаев, 1996. - Бутанаев В.Я. Традиционная культура и быт хакасов. Абакан: Хакасское кн. изд-во, 1996. - 224 с.

4. Бутанаев, 2003. - Бутанаев В.Я. Бурханизм тюрков Саяно-Алтая. Абакан: Издательство Хакасского государственного университета им. Н.Ф. Катанова, 2003. - 260 с.

5. Бутанаев, 2004. - Бутанаев В.Я. Степные законы Хонгорая. - Абакан: Изд-во Хак. гос. ун-та им. Н.Ф. Катанова, 2004. - 258 с.

6. Бутанаев, Бутанаева, 2008. - Бутанаев В.Я., Бутанаева И.И. Мир Хонгорского (хакасского) фольклора. Абакан: Издательство Хакасского государственного университета им. Н.Ф. Катанова, 2008. - 376 с. ил. 8. 
7. Вайнштейн, 1991. - Вайнштейн С.И. Мир кочевников Центральной Азии. - М.: Наука, 1991. 294, [2] с., [2] л. ил.

8. Вербицкий, 1893. - Вербицкий В.И. Алтайские инородцы: Сб. этногр. ст. и исслед. алтайск. миссионера, протоиер. В.И. Вербицкого, изд. Этногр. отд. Имп. О-ва любителей естествознания, антропологии и этнографии, состоящего при Моск. ун-те / под ред. А.А. Ивановского. - Москва: Скоропеч. А.А. Левенсон, 1893. XIV, 221 с.

9. Даржа, 2009. - Даржа В.К. Традиционные мужские занятия тувинцев. Кызыл: Тувинское книжное издательство, 2009. - 592 с.

10. Зыков, 1986. - Зыков Ф.М. Поселения, жилища и хозяйственные постройки якутов XIX начала XX в.: Историко-этнографическое исследование. Якутск, 1986. - 100 с.

11. Ильина, 2011. - Ильина О.П. Истоки зодчества Горного Алтая. - Горно-Алтайск: ОАО ГорноАлтайская типография, 2012. - 111 с.

12. Кимеев, Копытов, 2018. - Кимеев В.М., Копытов А.И. Горная Шория: история и современность. Историко-этнографические очерки. Кемерово: Примула. 2018. - 600 с.

13. Кузнецова, 1898. - Кузнецов А.А. Жилища, одежда и пища минусинских и ачинских инородцев. Красноярск: Типография Енисейского губернского управления, 1898. - 213 с.

14. Патачаков, 1982. - Патачаков К. М. Очерки материальной культуры хакасов. Абакан: Хакасское отделение Красноярского книжного изд-ва, 1982. - 88 с.

15. Полевые материалы автора: ПМА-1 - 2003 г. Республика Хакасия, Аскизский р-н, с. Верхний Аскиз. Информанты: Сунчугашев Семен Павлович, 1924 г.р.; Тахтараков Прокопий (Олка) Васильевич 1928 г.р.; с. Усть-Хойза, информант: Кичеев Гаврил Максимович, 1938 г.р.; с. ТюртТас, информант: Боргояков Илья Арминович 1931 г.р.

16. ПМА-2 - Полевые материалы автора. 2019 г. Республика Хакасия, Аскизский р-н с. Кызлас. Информанты: Пакачаков Максим Николаевич, 1942 г.р.; Кыржинаков Алексей Мартьянович, 1950 г.р. 17. ПМА-3 - Полевые материалы автора. 2004 г. Республика Хакасия, Аскизский р-н с. Картоев. Информанты: Тахтаракова Анисья (Ама) Васильевна 1917 г.р.; с. Кызлас Кыржинаков Алексей Мартьянович, 1950 г.р.

18. Потапов, 1957. - Потапов Л.П. Происхождение и формирование хакасской народности. Абакан: Хакасское книжное издательство, 1957. - 308 с.

19. Потапов, 2001. - Потапов Л.П. Охотничий промысел алтайцев: (отражение древнетюркской культуры в традиционном охотничьем промысле алтайцев). - СПб.: МАЭ им. Петра Великого (Кунсткамера), 2001. - 166 с.

20. Попов, 1961. - Попов А.А. Жилище // Историко-этнографический атлас Сибири. М.-Л.: АН СССР, 1961. - С. 131-225.

21. РФ ХакНИИЯЛИ - Рукописный фонд Хакасского научно-исследовательского института языка, литературы, истории. №. 341. Каралькин П. И. Земледелие и охота у бельтыров. (по материалам экспедиции в Аскизский и Таштыпский районы в 1947 г.) - 40 с.

22. РФ ХакНИИЯЛИ - Рукописный фонд Хакасского научно-исследовательского института языка, литературы, истории. Быт и культура хакасов в иллюстрациях (XIX - начало XX в.) / Составитель К.М. Патачаков, Абакан, 1994 (4 конверта, 110 листов (фотографии).

23. РФ ХакНИИЯЛИ - Рукописный фонд Хакасского научно-исследовательского института языка, литературы, истории. № 352. Шибаева Ю. А. Хакасское жилище. - 140 с.

24. РФ ХакНИИЯЛИ - Рукописный Фонд Хакасского научно-исследовательского института языка, литературы и истории. № 353. Шибаева Ю.А. Отчёт об этнографическом обследовании кызыльцев Ширинского и Саралинского районов в июле 1951 г. - 200 с.

25. РФ ХакНИИЯЛИ - Рукописный Фонд Хакасского научно-исследовательского института языка, литературы и истории. № 925. Патачаков К. М. Религиозно-бытовые пережитки у хакасов и пути их преодоления. л-9.

26. РФ ХакНИИЯЛИ - Рукописный фонд Хакасского научно-исследовательского института языка, литературы, истории. № 352 (приложение). Табл. № 2. Шибаева Ю. А. Чертежи по жилищу хакасов (55 чертежей).

27. Савинов, 1996. -- Савинов Д.Г. Древние поселения Хакасии. Торгажак. - СПб.: «Петербургское востоковедение», 1996. - 112 с.

28. Селезнев, Селезнева, Бельгибаев, 2006. - Селезнев А.Г., Селезнева И.А., Бельгибаев Е.А. Мир таежных культур (Традиционное хозяйство и сопутствующие компоненты жизнедеятельности). Отв. ред. Н. А. Томилов. Омск: Издательский дом «Наука», 2006. - 260 с.

29. Соколова, 1998. - Сколова 3. П. Жилище народов Сибири: (Опыт типологии) / Рос. акад. наук. Ин-т этнологии и антропологии им. Н.Н. Миклухо-Маклая. - М. : ИПА "Три Л", 1998. - 284 с. : ил. 30. Сравнительно-историческая грамматика тюркских языков, 2001. - Сравнительноисторическая грамматика тюркских языков. Лексика: 2-е изд., доп. М.: Наука, 2001. - 822 с.

31. Тюркские народы Сибири, 2006. - Тюркские народы Сибири / отв. ред. Д.А. Функ, Н.А. Томилов; Ин-т этнологии и антропологии им. Н.Н. Миклухо-Маклая РАН; Омский филиал Института археологии и этнографии СО РАН. - М.: Наука, 2006. - 678 с. - (Народы и культуры). 
32. Тюркские народы Восточной Сибири, 2008. - Тюркские народы Восточной Сибири / отв. ред. Д.А. Функ, Н.А. Алексеев; [сост. Д.А. Функ]; Ин-т этнологии и антропологии им. Н.Н. МиклухоМаклая РАН. - М.: Наука, 2008. - 422 с. - (Народы и культуры).

33. Шибаева, 1950. - Шибаева Ю.А. Из истории хакасского жилища // Краткие сообщения АН СССР. Вып. Х. М.-Л.: Изд-во АН СССР, 1950. - С. 46-53.

34. Ядринцев, 1891. - Ядринцев Н. М. Сибирские инородцы, их быт и современное положение: этнографические и статистические исследования с приложением статистических таблиц. СПб.: Издание И. М. Сибирякова, 1891. - 308 с.

35. Яковлев, 1900. - Яковлев Е.К. Этнографический обзор инородческого населения долины Южного Енисея и объяснительный каталог этнографического музея. Вып. 4 - Минусинск: Типография В.И. Корнакова, 1900. - 197 с.

\section{References}

Antologiya hakasskoj poezii, 1960. - Antologiya hakasskoj poezii /sost. U.N. Kirbizhekova, T.G. Tacheeva, P.A. Troyakov. Abakan: Hakasskaya oblastnaya tipografiya, 1960. - 164 s. [In Rus.]

Butanaev, 1987. - Butanaev V. YA. Social'no-ekonomicheskaya istoriya hakasskogo aala (konec $\mathrm{XIH}$ - nachalo HKH v.). - Abakan: Krasnoyar. kn. izd-vo, Hakas. otd-nie, 1987. - 175 s. [In Rus.]

Butanaev, 1996. - Butanaev V. YA. Tradicionnaya kul'tura i byt hakasov. Abakan: Hakasskoe kn. izdvo, 1996. - 224 s. [In Rus.]

Butanaev, 2003. - Butanaev V. YA. Burhanizm tyurkov Sayano-Altaya. Abakan: Izdatel'stvo Hakasskogo gosudarstvennogo universiteta im. N. F. Katanova, 2003. - 260 s. [In Rus.]

Butanaev, 2004. - Butanaev V. YA. Stepnye zakony Hongoraya. - Abakan: Izd-vo Hak. gos. un-ta im. N.F. Katanova, 2004. - 258 s. [In Rus.]

Butanaev, Butanaeva, 2008. - Butanaev V.YA., Butanaeva I.I. Mir Hongorskogo (hakasskogo) fol'klora. Abakan: Izdatel'stvo Hakasskogo gosudarstvennogo universiteta im. N.F. Katanova, 2008. - 376 s. il. 8. [In Rus.]

Vajnshtejn, 1991. - Vajnshtejn S. I. Mir kochevnikov Central'noj Azii. - M.: Nauka, 1991. - 294, [2] s., [2] I. il. [In Rus.]

Verbickij, 1893. - Verbickij V. I. Altajskie inorodcy: Sb. etnogr. st. i issled. altajsk. missionera, protoier V.I. Verbickogo, izd. Etnogr. otd. Imp. O-va lyubitelej estestvoznaniya, antropologii i etnografii, sostoyashchego pri Mosk. un-te / pod red. A. A. Ivanovskogo. - Moskva : Skoropech. A.A. Levenson, 1893. XIV, - $221 \mathrm{~s}$. [In Rus.]

Darzha, 2009. - Darzha V.K. Tradicionnye muzhskie zanyatiya tuvincev. Kyzyl: Tuvinskoe knizhnoe izdatel'stvo, 2009. - 592 s. [In Rus.]

Zykov, 1986. - Zykov F. M. Poseleniya, zhilishcha i hozyajstvennye postrojki yakutov XIX - nachala XX v.: Istoriko-etnograficheskoe issledovanie. YAkutsk, 1986. - 100 s. [In Rus.]

Il'ina, 2011. - Il'ina O. P. Istoki zodchestva Gornogo Altaya. - Gorno-Altajsk: OAO Gorno-Altajskaya tipografiya, 2012. - $111 \mathrm{~s}$. [In Rus.]

Kimeev, Kopytov, 2018. - Kimeev V.M., Kopytov A.I. Gornaya SHoriya: istoriya i sovremennost'. Istoriko-etnograficheskie ocherki. Kemerovo : Primula. 2018. - 600 s. [In Rus.]

Kuznecova, 1898. - Kuznecov A.A. ZHilishcha, odezhda i pishcha minusinskih i achinskih inorodcev. Krasnoyarsk: Tipografiya Enisejskogo gubernskogo upravleniya, 1898. - 213 s. [In Rus.]

Patachakov, 1982. - Patachakov K.M. Ocherki material'noj kul'tury hakasov. Abakan: Hakasskoe otdelenie Krasnoyarskogo knizhnogo izd-va, 1982. - 88 s. [In Rus.]

Polevye materialy avtora: PMA-1 - 2003 g. Respublika Hakasiya, Askizskij r-n, s. Verhnij Askiz. Informanty: Sunchugashev Semen Pavlovich, 1924 g.r.; Tahtarakov Prokopij (Olka) Vasil'evich 1928 g.r.; s. Ust' [In Rus.]

Hojza, informant: Kicheev Gavril Maksimovich, 1938 g.r.; s. Tyurt-Tas, informant: Borgoyakov II'ya Arminovich 1931 g.r. [In Rus.]

PMA-2 - Polevye materialy avtora. 2019 g. Respublika Hakasiya, Askizskij r-n s. Kyzlas. Informanty: Pakachakov Maksim Nikolaevich, 1942 g.r.; Kyrzhinakov Aleksej Mart'yanovich, 1950 g.r. [In Rus.]

PMA-3 - Polevye materialy avtora. 2004 g. Respublika Hakasiya, Askizskij r-n s. Kartoev. Informanty: Tahtarakova Anis'ya (Ama) Vasil'evna 1917 g.r.; s. Kyzlas Kyrzhinakov Aleksej Mart'yanovich, 1950 g.r. [In Rus.]

Potapov, 1957. - Potapov L.P. Proiskhozhdenie i formirovanie hakasskoj narodnosti. Abakan: Hakasskoe knizhnoe izdatel'stvo, 1957. - 308 s. [In Rus.]

Potapov, 2001. - Potapov L. P. Ohotnichij promysel altajcev: (otrazhenie drevnetyurkskoj kul'tury v tradicionnom ohotnich'em promysle altajcev). - SPb.: MAE im. Petra Velikogo (Kunstkamera), 2001. - 166 s. [In Rus.]

Popov, 1961. - Popov A. A. ZHilishche // Istoriko-etnograficheskij atlas Sibiri. M.-L.: AN SSSR, 1961. S. 131-225. 
RF HakNIIYALI - Rukopisnyj fond Hakasskogo nauchno-issledovatel'skogo instituta yazyka, literatury, istorii. №. 341. Karal'kin P. I. Zemledelie i ohota u bel'tyrov. (po materialam ekspedicii v Askizskij i Tashtypskij rajony v 1947 g.) - 40 s. [In Rus.]

RF HakNIIYALI - Rukopisnyj fond Hakasskogo nauchno-issledovatel'skogo instituta yazyka, literatury, istorii. Byt i kul'tura hakasov v illyustraciyah (XIX - nachalo XX v.) / Sostavitel' K.M. Patachakov, Abakan, 1994 (4 konverta, 110 listov (fotografii). [In Rus.]

RF HakNIIYALI - Rukopisnyj fond Hakasskogo nauchno-issledovatel'skogo instituta yazyka, literatury, istorii. № 352. SHibaeva YU. A. Hakasskoe zhilishche. - 140 s. [In Rus.]

RF HakNIIYALI - Rukopisnyj Fond Hakasskogo nauchno-issledovatel'skogo instituta yazyka, literatury $i$ istorii. № 353. SHibaeva YU. A. Otchyot ob etnograficheskom obsledovanii kyzyl'cev SHirinskogo i Saralinskogo rajonov v iyule 1951 g. - 200 s. [In Rus.]

RF HakNIIYALI - Rukopisnyj Fond Hakasskogo nauchno-issledovatel'skogo instituta yazyka, literatury i istorii. № 925. Patachakov K. M. Religiozno-bytovye perezhitki u hakasov i puti ih preodoleniya. I-9.

RF HakNIIYALI - Rukopisnyj fond Hakasskogo nauchno-issledovatel'skogo instituta yazyka, literatury, istorii. № 352 (prilozhenie). Tabl. № 2. SHibaeva YU. A. CHertezhi po zhilishchu hakasov (55 chertezhej).

Savinov, 1996. - Savinov D.G. Drevnie poseleniya Hakasii. Torgazhak. - SPb.: «Peterburgskoe vostokovedenie», 1996. - 112 s. [In Rus.]

Seleznev, Selezneva, Bel'gibaev, 2006. - Seleznev A.G., Selezneva I. A., Bel'gibaev E.A. Mir taezhnyh kul'tur (Tradicionnoe hozyajstvo i soputstvuyushchie komponenty zhiznedeyatel'nosti). Otv. red. N.A. Tomilov. Omsk: Izdatel'skij dom «Nauka», 2006. - 260 s. [In Rus.]

Sokolova, 1998. - Skolova Z.P. ZHilishche narodov Sibiri: (Opyt tipologii) / Ros. akad. nauk. In-t etnologii i antropologii im. N.N. Mikluho-Maklaya. - M. : IPA "Tri L", 1998. - 284 s. : il. [In Rus.]

Sravnitel'no-istoricheskaya grammatika tyurkskih yazykov, 2001. - Sravnitel'no-istoricheskaya grammatika tyurkskih yazykov. Leksika: 2-e izd., dop. M.: Nauka, 2001. - 822 s. [In Rus.]

Tyurkskie narody Sibiri, 2006. - Tyurkskie narody Sibiri / otv. red. D. A. Funk, N. A. Tomilov; In-t etnologii i antropologii im. N.N. Mikluho-Maklaya RAN ; Omskij filial Instituta arheologii i etnografii SO RAN. - M.: Nauka, 2006. - 678 s. - (Narody i kul'tury). [In Rus.]

Tyurkskie narody Vostochnoj Sibiri, 2008. - Tyurkskie narody Vostochnoj Sibiri / otv. red. D.A. Funk, N.A. Alekseev; [sost. D.A. Funk]; In-t etnologii i antropologii im. N.N. Mikluho-Maklaya RAN. - M.: Nauka, 2008. - 422 s. - (Narody i kul'tury). [In Rus.]

SHibaeva, 1950. - SHibaeva YU. A. Iz istorii hakasskogo zhilishcha // Kratkie soobshcheniya AN SSSR. Vyp. H. M.-L.: Izd-vo AN SSSR, 1950. S. 46-53.[In Rus.]

YAdrincev, 1891. - YAdrincev N. M. Sibirskie inorodcy, in byt i sovremennoe polozhenie: etnograficheskie i statisticheskie issledovaniya s prilozheniem statisticheskih tablic. SPb.: Izdanie I. M. Sibiryakova, 1891. - 308 s. [In Rus.]

YAkovlev, 1900. - YAkovlev E. K. Etnograficheskij obzor inorodcheskogo naseleniya doliny YUzhnogo Eniseya i ob"yasnitel'nyj katalog etnograficheskogo muzeya. Vyp. 4 - Minusinsk: Tipografiya V.I. Kornakova, 1900. - 197 s. [In Rus.] 